\title{
Tumor Necrosis Factor- $\alpha$ Mediates Oligodendrocyte Death and Delayed Retinal Ganglion Cell Loss in a Mouse Model of Glaucoma
}

\author{
Toru Nakazawa, ${ }^{1,2,3,4}$ Chifuyu Nakazawa, ${ }^{1,3}$ Akihisa Matsubara, ${ }^{1,3}$ Kousuke Noda, ${ }^{1,3}$ Toshio Hisatomi, ${ }^{1,3}$ Haicheng She, ${ }^{1,3}$ \\ Norman Michaud, ${ }^{1,3}$ Ali Hafezi-Moghadam, ${ }^{1,3}$ Joan W. Miller, ${ }^{1,3}$ and Larry I. Benowitz ${ }^{2,4}$ \\ ${ }^{1}$ Angiogenesis Laboratory, Massachusetts Eye and Ear Infirmary, Boston, Massachusetts 02114, ${ }^{2}$ Department of Neurosurgery and Neurobiology Program, \\ Children's Hospital Boston, Boston, Massachusetts 02115, and Departments of ${ }^{3}$ Ophthalmology and ${ }^{4}$ Surgery and Program in Neuroscience, Harvard \\ Medical School, Boston, Massachusetts 02115
}

\begin{abstract}
Glaucoma is a widespread ocular disease characterized by a progressive loss of retinal ganglion cells (RGCs). Previous studies suggest that the cytokine tumor necrosis factor- $\alpha$ (TNF- $\alpha$ ) may contribute to the disease process, although its role in vivo and its mechanism of action are unclear. To investigate pathophysiological mechanisms in glaucoma, we induced ocular hypertension $(\mathrm{OH})$ in mice by angle closure via laser irradiation. This treatment resulted in a rapid upregulation of TNF- $\alpha$, followed sequentially by microglial activation, loss of optic nerve oligodendrocytes, and delayed loss of RGCs. Intravitreal TNF- $\alpha$ injections in normal mice mimicked these effects. Conversely, an anti-TNF- $\alpha$-neutralizing antibody or deleting the genes encoding TNF- $\alpha$ or its receptor, TNFR2, blocked the deleterious effects of $\mathrm{OH}$. Deleting the CD11b/CD18 gene prevented microglial activation and also blocked the pathophysiological effects of OH. Thus TNF- $\alpha$ provides an essential, although indirect, link between $\mathrm{OH}$ and RGC loss in vivo. Blocking TNF- $\alpha$ signaling or inflammation, therefore, may be helpful in treating glaucoma.
\end{abstract}

Key words: glaucoma; retinal ganglion cell; optic nerve; cytokines; oligodendrocyte; microglia

\section{Introduction}

Glaucoma affects > 70 million people worldwide (Quigley, 1996; Resnikoff et al., 2004) and is associated with an optic nerve fiber atrophy that results in progressive visual loss (Weinreb and Khaw, 2004). Although increased intraocular pressure (IOP) is recognized widely as a major risk factor, the pathogenesis of the disease remains unclear. Lowering IOP is currently the only standard treatment to prevent disease progression, although some patients with significant IOP reduction (Heijl et al., 2002) or even normal IOP (Iwase et al., 2004) still show disease progression. Among the cells in the eye, the retinal ganglion cells (RGCs) are particularly vulnerable in glaucoma (Levin, 2003). Neuroprotection of RGCs has been emphasized as an important goal for managing the disease (Levin, 2003), although this has yet to achieved.

Tumor necrosis factor- $\alpha$ (TNF- $\alpha$ ) is synthesized primarily by

Received June 30, 2006; revised Sept. 18, 2006; accepted 0ct. 22, 2006

This work was supported by an Alcon Research Award (to J.W.M.), Bausch \& Lomb Vitreoretinal Fellowship (to T.N.), National Institutes of Health Grant K08AI50775 (to A.H.M.), and National Eye Institute Grants EY014104 (Massachusetts Eye and Ear Infirmary Core Grant) and EY05690 (to L.I.B.). We thank Sreedevi Mallemadugula for technical assistance.

Correspondence should be addressed to either of the following: Dr. Larry Benowitz, Department of Neurosurgery and Neurobiology Program, Children's Hospital Boston, 300 Longwood Avenue, Boston, MA 02115, E-mail: larry.benowitz@childrens.harvard.edu; or Dr. Joan W. Miller, Angiogenesis Laboratory, Massachusetts Eye and Ear Infirmary, 243 Cambridge Street, Boston, MA 02114, E-mail: Joan_Miller@meei.harvard.edu.

T. Nakazawa's present address: Department of Ophthalmology, Tohoku University School of Medicine, Aoba-ku, Sendai 980-8575, Japan.

DOI:10.1523/JNEUROSCI.2801-06.2006

Copyright $\odot 2006$ Society for Neuroscience $\quad$ 0270-6474/06/2612633-09\$15.00/0 activated monocytes as a $26 \mathrm{kDa}$ precursor (Brouckaert et al., 1993) that is cleaved proteolytically and secreted as a $17 \mathrm{kDa}$ protein (Moss et al., 1997). TNF- $\alpha$ acts via either the low-affinity TNF receptor (TNFR1) or high-affinity TNF receptor (TNFR2) (Tartaglia and Goeddel, 1992). TNF- $\alpha$ is upregulated in several neurodegenerative disorders including multiple sclerosis, Parkinson's disease, and Alzheimer's disease (Shohami et al., 1999) and in optic nerve microglia and astrocytes of glaucoma patients (Yan et al., 2000; Yuan and Neufeld, 2000, 2001). TNF- $\alpha$ gene polymorphisms increase the risk for glaucoma (Funayama et al., 2004 ), suggesting that TNF- $\alpha$ may contribute to the pathogenesis of the disease. TNF- $\alpha$ is toxic to immunopurified RGCs and to RGCs in mixed cultures when glia are stressed, although not under resting conditions (Tezel and Wax, 2000; Fuchs et al., 2005). In vivo, exogenous TNF- $\alpha$ prevents RGC death after optic nerve damage (Diem et al., 2001), although other studies show that it can cause the loss of RGC axons and a delayed loss of somata (Kitaoka et al., 2006). As yet, there is no direct evidence that TNF- $\alpha$ contributes to RGC death in glaucoma, nor is there any mechanistic understanding of how this might occur.

The loss of RGCs is delayed by several weeks after elevating IOP in experimental glaucoma models (Cordeiro et al., 2004; Huang et al., 2005b; Ji et al., 2005). Because of the difficulty in manipulating important molecules over this duration, genetically altered mice are ideal for investigating the significance of candidate molecules in disease progression. Although the establishment of the DBA/2J mouse line with a spontaneous mutation that leads to glaucoma has contributed greatly to research in this 
field, the use of these animals for investigating pathophysiological mechanisms is limited by a relatively long delay in RGC loss and by considerable inter-individual variability (John, 2005). Laser-induced glaucoma models allow for a convenient, rapid induction of ocular hypertension $(\mathrm{OH})$ and can be done in genetically altered mice to study molecular mechanisms underlying RGC loss (Lindsey and Weinreb, 2005). Using a laser-induced $\mathrm{OH}$ model in mice, we find that $\mathrm{OH}$ induces TNF- $\alpha$ upregulation in the retina, which ultimately leads to RGC loss via microglial activation and oligodendrocyte death.

\section{Materials and Methods}

Animals and reagents. Animals were housed under constant $12 \mathrm{~h}$ light/ dark cycles in covered cages and were fed with a standard rodent diet $a d$ libitum. TNF- $\alpha$ (background, B6.129SF2J), TNFR1, TNFR2, and macrophage antigen-1 (Mac-1; background, C57BL/6) male knock-out mice aged 2-4 months were used in the experimental glaucoma model or for intravitreal administration of TNF- $\alpha$ or the blocking antibody. C57BL/6 and B6.129SF2J male mice aged 2-4 months were used as wild-type controls where appropriate. All mice were purchased from The Jackson Laboratory (Bar Harbor, ME) and were bred in the Massachusetts Eye and Ear Infirmary (MEEI; Boston, MA) animal facility. Quantitation of retrogradely labeled cells revealed no differences in total numbers of RGCs among strains (supplemental Table 1, available at www.jneurosci.org as supplemental material). Mouse recombinant TNF- $\alpha$ was purchased from Preprotech (Rocky Hill, NJ). Goat anti-mouse TNF- $\alpha$ blocking antibody and the appropriate control antibody were from R \& D Systems (Minneapolis, MN). 1,1'-Dioctadecyl-3,3,3',3'-tetramethylindocarbocyanine perchlorate (DiI) was purchased from Invitrogen (Carlsbad, CA).

Experimental mouse glaucoma model. All experiments were performed in accordance with the Association for Research in Vision and Ophthalmology Statement for the Use of Animals in Ophthalmic and Vision Research, using a protocol approved by the Animal Care Committee of the MEEI. The right eye of each animal was used as the experimental side, and the left eye served as a control. For general anesthesia a mixture of ketamine (100 mg/kg; Phoenix Scientific, St. Joseph, MO) and xylazine (10 mg/kg; Phoenix Scientific) was administered intramuscularly. To induce chronically high IOP, we flattened the anterior chamber of 8 -week-old mice and obstructed the aqueous flow by angle closure via argon laser irradiation. The procedure used here follows previous descriptions with minor modifications (Aihara et al., 2003). Briefly, the right pupil was dilated with a topically applied mixture of phenylephrine $(5.0 \%)$ and tropicamide $(0.8 \%) 10 \mathrm{~min}$ before laser irradiation. The anterior chamber was flattened by aspirating aqueous fluid with a 30 gauge needle. Immediately after the anterior chamber was flattened, laser photo coagulation of the limbus was performed with a slit lamp biomicroscope equipped with an argon laser system (532 nm; Elite, HGM Medical Laser Systems, Salt Lake City, UT). The spot size, laser power, and duration were $200 \mu \mathrm{m}, 100 \mathrm{~mW}$, and $0.1 \mathrm{~s}$, respectively. The laser beam was focused directly on the corneal limbus, and $100 \pm 10$ (mean \pm $\mathrm{SD}$ ) spots were placed confluently. As a control the same number of laser spots was placed on the iris near the pupil. These procedures were completed within $10 \mathrm{~min}$ per animal. After treatment $0.1 \%$ atropine and an antibiotic ointment were administered to the cornea.

IOP measurement. IOP was measured by using the applanation tonometer described previously (Matsubara et al., 2006). This instrument consists of a fiber optic pressure sensor and a Fabry-Pérot interferometer (FPI) (FTI-10, FISO Technologies, Quebec, Canada). The sensor is designed to measure the pressure on the surface of a fiber tip (550 $\mu \mathrm{m})$ and provides high-fidelity performance and in situ pressure measurement via a minimally invasive procedure. The instrument averages data obtained from 10 repeated pressure measurements via a tip attached to the mouse corneal surface. IOP was always measured in the morning under general anesthesia, typically within $2-3 \mathrm{~min}$ after the animal lost consciousness and failed to respond to touch. Anesthetized mice were placed on a platform, and the tip of the pressure sensor was attached to a central area of the mouse cornea under microscopic guidance. Average IOP was displayed automatically after 10 measurements. IOP was mea-

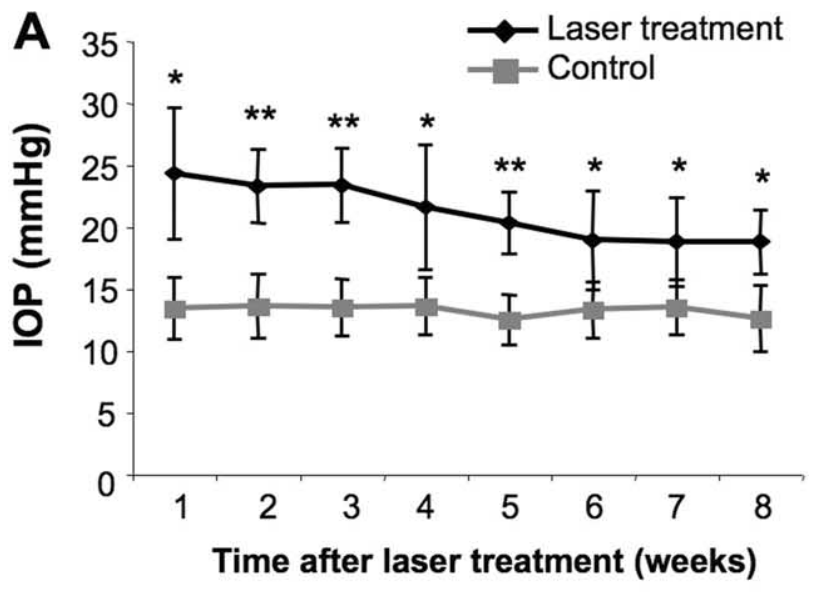

B

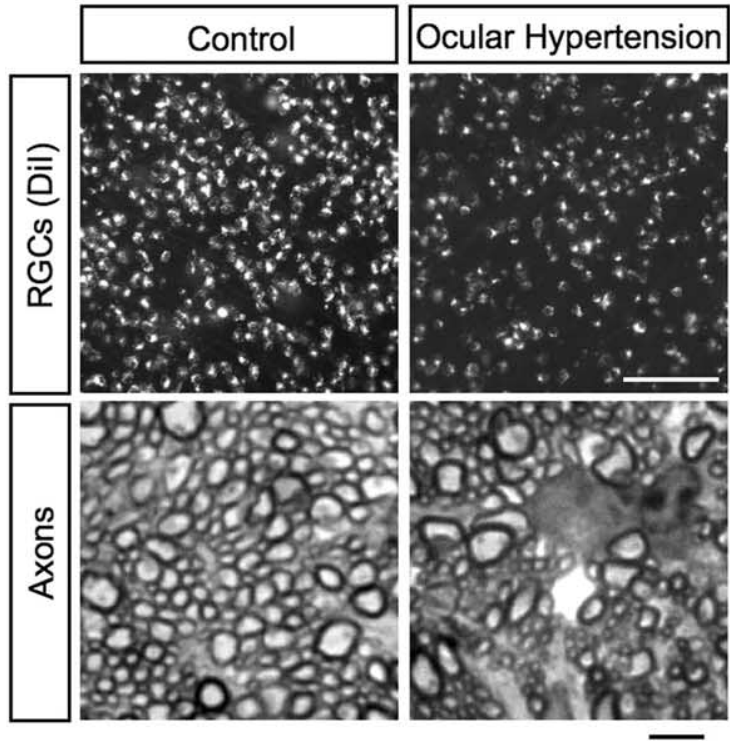

C

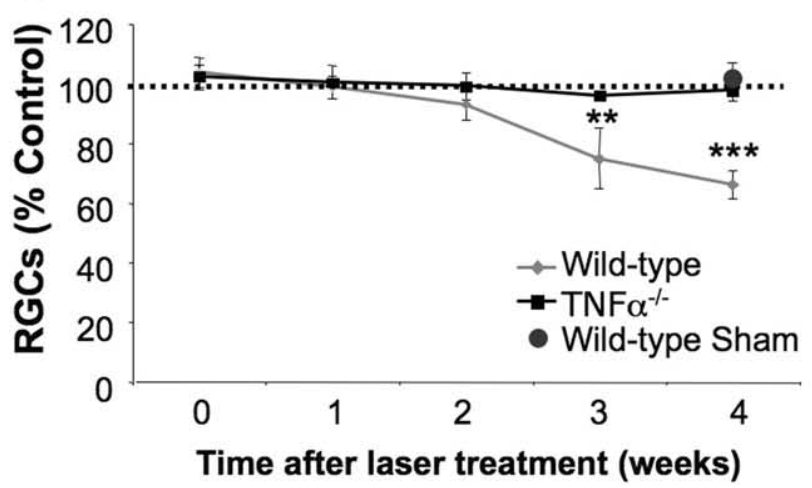

Figure 1. Laser-induced angle closure leads to increased intraocular pressure and loss of $\mathrm{RGCS}$ and axons. $\boldsymbol{A}$, Time course of IOP after laser-induced angle closure ( $n=15$ per time point). Pressure was measured at the indicated time points with an applanation tonometer. ${ }^{*} p<0.05$ and ${ }^{* *} p<0.01$ compared with the contralateral control eye. $\boldsymbol{B}$, Dil-labeled RGCs in flatmounted retinas (top panels; scale bar, $100 \mu \mathrm{m}$ ) and axons (bottom panels; scale bar, $10 \mu \mathrm{m}$ ) of control or $\mathrm{OH}$ mice 4 weeks after increasing IOP. C, Quantitation of Dil-labeled RGCs in wildtype and TNF- $\alpha^{-1-}$ mice after elevation of IOP. ${ }^{* *} p<0.01$ and ${ }^{* * *} p<0.001$ compared with wild-type mice ( $n=10$ per time point).

sured in both eyes weekly over an 8 week period after laser irradiation. We excluded mice from our experimental group in which IOP was not increased $>30 \%$ above baseline in the first measurement and included these as a sham-operated control group. 
Intravitreal injection and retrograde labeling of RGCs. Intravitreal administration of TNF- $\alpha$ ( $1 \mathrm{ng}$ in $1 \mu \mathrm{l}$ of PBS with $0.1 \%$ BSA) and retrograde labeling of RGCs with DiI were performed as described with minor modification (Nakazawa et al., 2002b). DiI was prepared as a $2 \%$ solution in dimethylsulfoxide. Under anesthesia the skin over the cranium was incised, the scalp was exposed, and holes $\sim 1 \mathrm{~mm}$ in diameter were drilled in the skull $4 \mathrm{~mm}$ posterior to the bregma and $1 \mathrm{~mm}$ lateral to the midline on both sides. DiI solution was injected $(1 \mu \mathrm{l} ; 0.5 \mu \mathrm{l} / \mathrm{min})$ at a depth of 2 $\mathrm{mm}$ from the brain surface with a Hamilton syringe (Hamilton, Reno, NV). Skull openings were sealed with antibiotic ointment, the overlying skin was sutured, and antibiotic ointment was applied externally. Laserinduced angle closure or intravitreal injections were performed $7 \mathrm{~d}$ after retrograde labeling. DiI-labeled RGCs were counted at various survival times as described previously (Nakazawa et al., 2002b) under fluorescent microscopy (Leica Microsystems, Wetzlar, Germany) with the use of a rhodamine filter set. Cell survival was determined by counting labeled RGCs in 12 distinct areas of $9.0 \times 10^{-2} / \mathrm{mm}^{2}$ each (three areas per retinal quadrant at one-sixth, three-sixths, and five-sixths of the retinal radius). The density of RGCs was defined as the average number of cells in the 12 fields. Cell counting was performed in a masked manner.

Histological procedures for optic nerve analysis. For quantitative analyses we analyzed at least three sections from each of eight mice for each experimental condition. Optic nerves were placed immediately into fixative consisting of $2.5 \%$ glutaraldehyde and $2 \%$ formaldehyde in $0.1 \mathrm{M}$ cacodylate buffer with $0.08 \mathrm{M} \mathrm{CaCl}_{2}$ overnight at $4^{\circ} \mathrm{C}$. The tissue was washed in $0.1 \mathrm{M}$ cacodylate buffer and postfixed in $2 \%$ aqueous $\mathrm{OsO}_{4}$. Segments were dehydrated in graded alcohols and embedded in Epon. Then $1 \mu \mathrm{m}$ sections were cut and stained with $1 \%$ toluidine blue in $1 \%$ borate buffer.

Immunohistochemistry. Immunohistochemistry (IHC) was performed as described previously (Nakazawa et al., 2002b; Yin et al., 2006). Sections through the retina $(10 \mu \mathrm{m})$ with the optic nerve attached were preblocked (PBS containing 10\% goat serum, $0.5 \%$ gelatin, $3 \%$ BSA, and $0.2 \%$ Tween 20 ) and then incubated with mouse monoclonal antiadenomatous polyposis coli (APC) as a marker for oligodendrocytes (clone CC-1, 1:50; EMD Biosciences, San Diego, CA) or rat anti-mouse $\mathrm{CD} 11 \mathrm{~b}$ as a marker for microglia (Serotec, Raleigh, NC). The reaction buffer without the primary antibody served as a negative control. The secondary antibody was a goat anti-mouse or rat IgG conjugated to Alexa Fluor 488 (Invitrogen). Sections were mounted with Vectashield mounting medium with 4',6-diamidino-2-phenyindole (DAPI; Vector Laboratories, Burlingame, CA). For quantitation the images of $\mathrm{APC}^{+}$oligodendrocytes or $\mathrm{CD} 11 \mathrm{~b}^{+}$microglia were captured from optic nerve sections at a distance of $1 \mathrm{~mm}$ behind the eye. All cell counting was performed in a masked manner.

Real-time reverse transcription-PCR analysis for TNF- $\alpha$. Total RNA extraction and real-time PCR were performed as previously reported with minor modifications (Nakazawa et al., 2005). Briefly, total RNA was extracted (RNA Purification System, Invitrogen) from retinas homogenized with $600 \mu \mathrm{l}$ of RNA lysis buffer and mixed with an equivalent volume of $70 \%$ ethanol. The mixture was applied to an RNA spin cartridge, centrifuged at $12,000 \times g$ for $15 \mathrm{~s}$ at $25^{\circ} \mathrm{C}$, and rinsed with wash buffers I and II. Total RNA was eluted with $20 \mu \mathrm{l}$ of RNase-free water. Total RNA $(3 \mu \mathrm{g})$ was reverse-transcribed by using the SuperScript III First-Strand Synthesis System (Invitrogen), and first-strand cDNAs were amplified by using a real-time PCR thermal cycler (ABI7700, Applied Biosystems, Foster City, CA). Quantitative real-time PCR was performed with TaqMan Universal PCR Master Mix kit (Applied Biosystems) according to the manufacturer's guidelines. PCR primers for TNF- $\alpha$ used in this study include mouse TNF- $\alpha$ (mTNF- $\alpha$ ) forward, 5' CATCAGTTCTATGGCCCAGACCCT- $3^{\prime}$, and mTNF- $\alpha$ reverse, $5^{\prime}$ GCTCCTCCACTTGGTGGTTTGCTA-3', plus mTNF- $\alpha$, VIC-TCA GAT CAT CTT CTC AAA ATT CGA GTG ACA AGC CT-TAMRA. PCR products were confirmed by agarose gel electrophoresis and sequencing. For relative comparison of each gene we analyzed the cycle of threshold (Ct) value of real-time PCR data with the $\delta$ - $\delta$ Ct method according to the company's instructions (Nakazawa et al., 2005). To normalize the amount of sample cDNA added to each reaction, we subtracted the $\mathrm{Ct}$ value of each target gene from the $\mathrm{Ct}$ value of the endogenous control
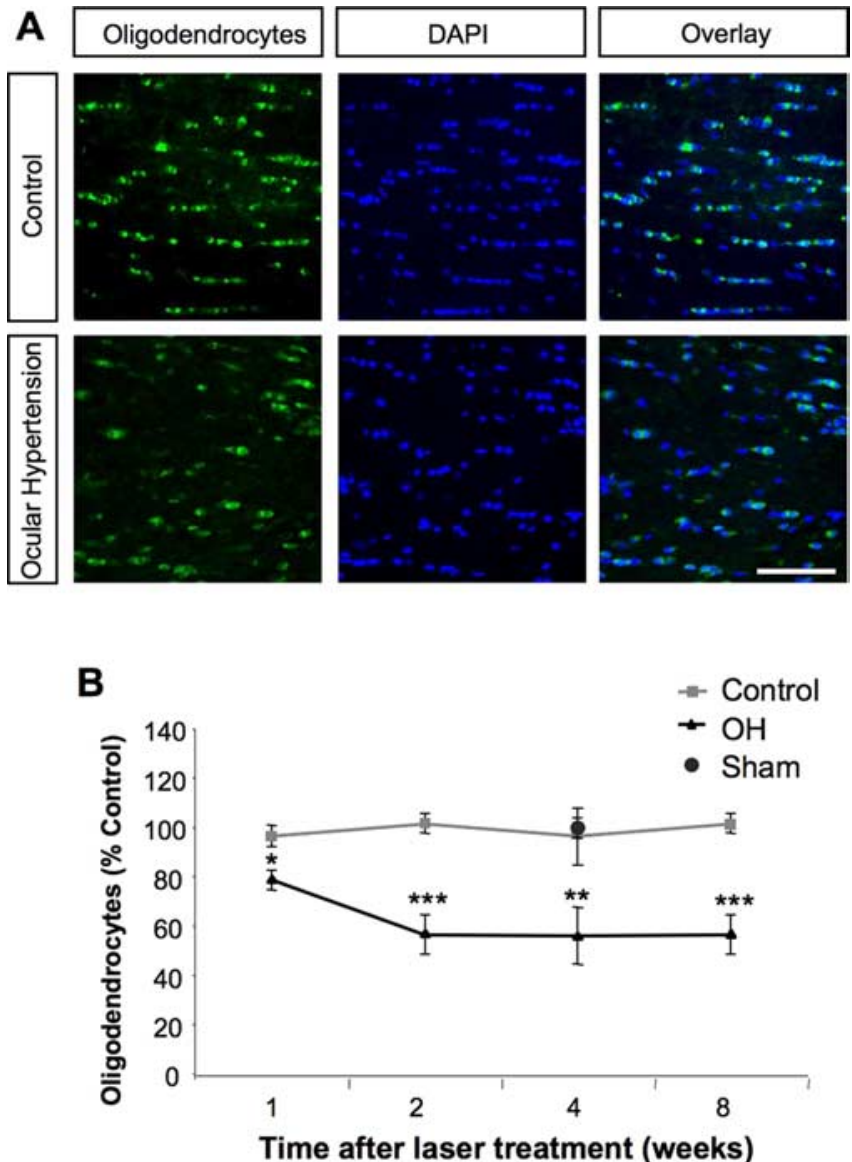

Figure 2. Loss of oligodendrocytes after $\mathrm{OH} . \mathrm{A}_{1} \mathrm{APC}^{+}$oligodendrocytes in retinas with or without $\mathrm{OH}$ at 8 weeks after surgery. Scale bar, $50 \mu \mathrm{m}$. $B$, Time course of oligodendrocyte survival after increasing IOP. ${ }^{*} p<0.05,{ }^{* *} p<0.01$, and ${ }^{* * *} p<0.001$ compared with normal controls ( $n=8$ per time point). Circle, Sham-operated controls $(n=6)$; triangle, $\mathrm{OH}$; square, control.

[Rodent GAPDH (glyceraldehyde phosphate dehydrogenase) Control Reagents, Applied Biosystems].

ELISA. The tissue complex containing the posterior lens capsule, vitreous, and neural retina was collected at 3, 7, and $14 \mathrm{~d}$ after laser-induced angle closure. Proteins were extracted in $100 \mu \mathrm{l}$ of PBS containing a protease inhibitor mixture (Complete, Roche Diagnostics, Pleasanton, CA) and sonicated ( $10 \mathrm{~W}, 5 \mathrm{~s}, 4^{\circ} \mathrm{C}$; Sonifier 250, Branson, Danbury, CT). The supernatant was collected after centrifugation at $14,000 \times g$ for 20 min at $4^{\circ} \mathrm{C}$ (Micromax RF, IEC, Needham Heights, MA), and the total protein concentration was measured with the DC protein assay kit (BioRad, Hercules, CA). Total protein $(100 \mu \mathrm{g})$ was used for ELISA (R \& D Systems), performed according to the manufacturer's guidelines. The absorbance at $450 \mathrm{~nm}$ was measured by using a 96 -well plate spectrophotometer (Spectramax 190, Molecular Devices, Sunnyvale, CA).

Statistical analysis. Statistical analysis of the reverse transcriptionPCR, ELISA, and cell counting data was performed by using unpaired Student's $t$ tests with StatView software (version 4.11J, Abacus Concepts, Berkeley, CA) on a Macintosh computer. All values are expressed as the mean \pm SD unless noted otherwise.

\section{Results}

Establishment of an experimental glaucoma model in mice In glaucoma patients, increased IOP is the most important risk factor for the loss of RGC axons and somata. To mimic this disease in mice, we used a slight modification of a previously established method (Aihara et al., 2003) to increase IOP by angle closure via laser photo coagulation. Laser photo coagulation 
blocks the normal aqueous flow and, in our hands, increased IOP from a normal value of 14 to $24.5 \mathrm{mmHg}$ in $75 \%$ of treated cases at 1 week. IOP remained elevated in these cases for at least 8 weeks (Fig. $1 A$ ). We next investigated whether increased IOP in mice leads to the hallmark features of glaucoma, a loss of RGC axons and somata. At 2 weeks after angle closure the number of intact DiI-labeled RGCs was slightly, although not significantly, lower than in normal controls (Fig. $1 C)$, but by 4 weeks the number of RGCs in affected eyes was $28 \%$ lower than in the control contralateral eyes (Fig. $1 B, C$ ). As expected, the density of axons in cross sections through the optic nerve also declined on the side with increased IOP (Fig. $1 B$ ). Whereas myelinated axons show a homogeneous appearance in control optic nerves (Fig. $1 B$ ), the caliber of myelinated axons was heterogeneous 4 weeks after increasing IOP, with vacuoles and large cells evident. Thus, in conformity with earlier reports in rats (Cordeiro et al., 2004; Huang et al., 2005b), laser-induced $\mathrm{OH}$ caused a loss of RGC somata and axons. These losses were not detected in lasertreated eyes that did not exhibit increased IOP (Fig. $1 C$, circle).

\section{Oligodendrocyte degeneration in the mouse model}

Oligodendrocytes are the most abundant cells in the optic nerve, ensheathing the axons that arise from RGCs. We investigated whether $\mathrm{OH}$ has an impact on these cells and, if so, how this might relate to the loss of axons. With the use of an antibody against the oligodendrocyte marker APC, IHC revealed that the number of $\mathrm{APC}^{+}$cells seen in longitudinal sections of the optic nerve decreased to $80 \%$ of control levels 1 week after laser-induced angle closure and to $55 \%$ of control levels by 2 weeks. This number remained constant over the next several weeks (Fig. 2A,B). Thus oligodendrocyte degeneration precedes RGC loss. Oligodendrocyte degeneration was not detected in the laser-treated eyes that failed to show increased IOP (Fig. $2 B$, circle).

\section{TNF- $\alpha$ increases after $\mathrm{OH}$ induction}

Previous studies have reported elevated TNF- $\alpha$ levels in the retina and optic nerve head of glaucoma patients (Yan et al., 2000; Yuan and Neufeld, 2000, 2001). To investigate whether this occurs in our experimental model, we measured TNF- $\alpha$ levels in the retina of mice with or without elevated IOP. Real-time PCR showed that TNF- $\alpha$ mRNA levels increased almost fivefold relative to shamoperated controls $3 \mathrm{~d}$ after increasing IOP and remained elevated for at least $14 \mathrm{~d}$ (Fig. $3 A$ ). At the protein level ELISA revealed that TNF- $\alpha$ expression increased approximately threefold $3 \mathrm{~d}$ after elevating IOP and remained high for at least 2 weeks (Fig. $3 B$ ). Thus $\mathrm{OH}$ led to a rapid upregulation of TNF- $\alpha$ in this experimental model.

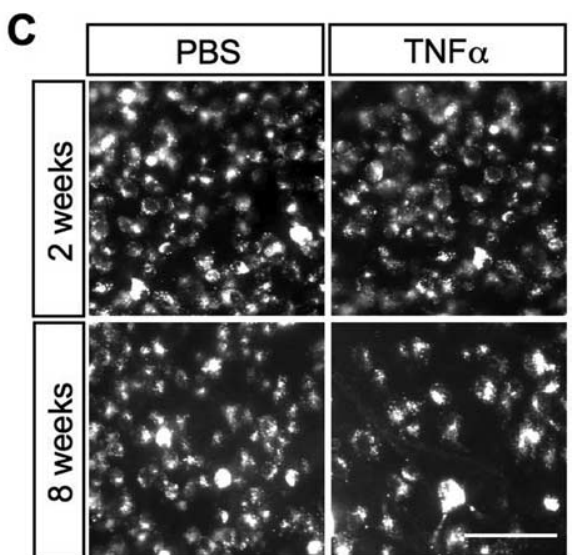

D

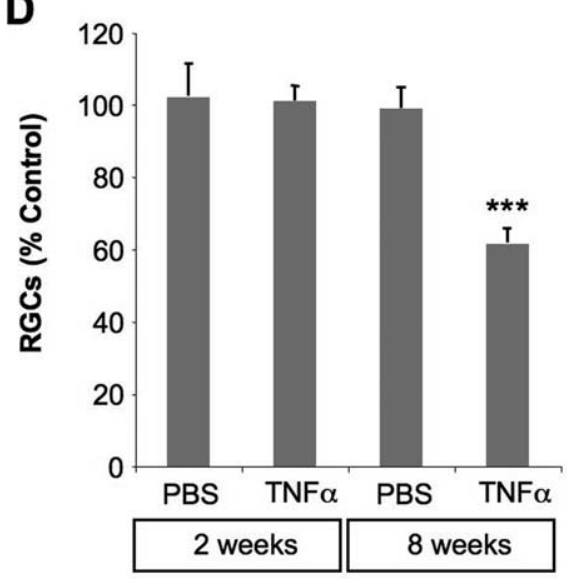

Figure 3. TNF- $\alpha$ levels increase after elevating IOP and result in a delayed loss of RGCs. $\boldsymbol{A}$, Real-time PCR analysis of TNF- $\alpha$ bar, $50 \mu \mathrm{m}$. D, Quantitation of RGC survival at 2 or 8 weeks after intravitreal injection of TNF- $\alpha .{ }^{* * *} p<0.001$ compared with controls injected with PBS at 8 weeks ( $n=8$ per time point).

Intravitreal administration of TNF- $\alpha$ mimics the pathophysiological effects of $\mathrm{OH}$

To investigate whether TNF- $\alpha$ plays a causative role in the loss of RGCs, we injected TNF- $\alpha$ ( $1 \mathrm{ng}$ ) into the mouse vitreous and quantified DiI-labeled RGCs in retinal whole mounts after either 2 or 8 weeks. The number of surviving RGCs remained normal 2 weeks after a single TNF- $\alpha$ injection but declined by $39 \%$ by 8 weeks (Fig. 3C,D). Thus, like OH, TNF- $\alpha$ induced a delayed loss of RGCs.

As noted above, elevation of IOP leads to a loss of oligodendrocytes, followed by a loss of RGCs. To investigate whether TNF- $\alpha$ might account for these losses, we performed immunohistochemistry to evaluate the number of $\mathrm{APC}^{+}$oligodendrocytes in optic nerve sections at various times after injecting TNF- $\alpha$ into the vitreous. The number of oligodendrocytes remained unchanged at $9 \mathrm{~h}$ and $1 \mathrm{~d}$ after TNF- $\alpha$ injections (Fig. $4 G$ ), but by $1 \mathrm{~d}$ these cells appeared to be disorganized (Fig. 4, compare $B, A)$. By day 4 the number of surviving oligodendrocytes had declined significantly (Fig. $4 C, G$ ), and at $14 \mathrm{~d}<50 \%$ of these cells remained. We also investigated the effects of direct TNF- $\alpha$ application by placing Spongels soaked in TNF- $\alpha$ ( $1 \mathrm{ng} /$ $\mathrm{ml}$ ) around the optic nerve. By day 14 this resulted in the loss of $\sim 40 \%$ of oligodendrocytes (Fig. $4 E, G$, circle). Together, these 

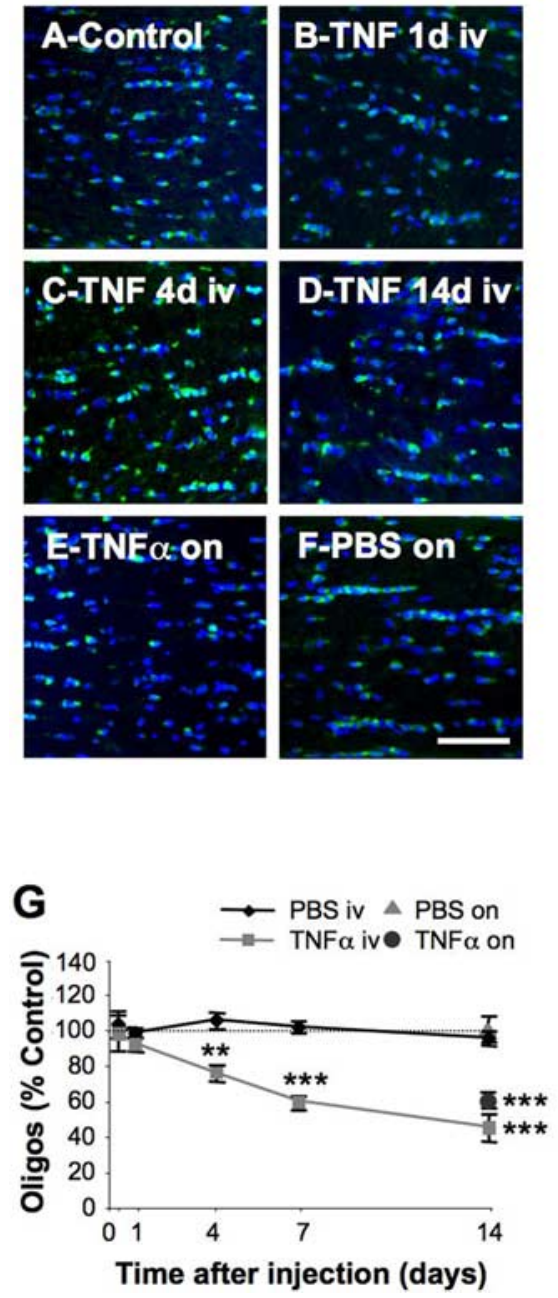

Figure 4. TNF- $\alpha$ mediates the effect of increased IOP on oligodendrocytes. $\boldsymbol{A}-\boldsymbol{F}$, Representative merged photomicrographs showing APC ${ }^{+}$oligodendrocytes (green) and DAPI nuclear staining (blue) in longitudinal sections through the optic nerve with or without TNF- $\alpha$ treatment. Shown are control $(\boldsymbol{A})$ and $1 \mathrm{~d}(\boldsymbol{B}), 4 \mathrm{~d}(\boldsymbol{C})$, and $14 \mathrm{~d}(\boldsymbol{D})$ after TNF- $\alpha$ injection. $\boldsymbol{E}, \boldsymbol{F}, \mathrm{APC}^{+}$oligoden- $^{-}$ drocytes in the optic nerve after direct contact with a Spongel soaked in $1 \mathrm{ng} / \mathrm{ml}$ TNF- $\alpha$ solution $(\boldsymbol{E})$ or PBS (F) after $14 \mathrm{~d}$. Scale bar, $50 \mu \mathrm{m} . \mathbf{G}$, Time course of oligodendrocyte degeneration after intravitreal administration of PBS (diamond) or TNF- $\alpha$ (square). Also shown are survival data $14 \mathrm{~d}$ after direct administration of PBS (triangle) or TNF- $\alpha$ (circle) to the optic nerve. ${ }^{* *} p<0.01$, ${ }^{* * *} p<0.001$ compared with PBS-treated controls ( $n=8$ per time point). $\boldsymbol{H}, \mathrm{APC}{ }^{+}$oligodendrocytes in optic nerves treated with anti-TNF- $\alpha$ blocking antibody or normal goat serum (NGS) $14 \mathrm{~d}$ after inducing $\mathrm{OH}$. Scale bar, $50 \mu \mathrm{m}$. I, Quantitation of OH-induced oligodendrocyte degeneration after $14 \mathrm{~d}$. ${ }^{* * *} p<0.001$ compared with normal controls $(n=8)$. J, Quantitation of OH-induced oligodendrocyte degeneration $14 \mathrm{~d}$ after inducing $\mathrm{OH}$ in wild-type or TNF- $\alpha^{-1-}$ mice. ${ }^{* *} p<0.001$ compared with normal control $(n=8)$.

results show that TNF- $\alpha$ mimics the effects of $\mathrm{OH}$, including a rapid loss of optic nerve oligodendrocytes and a delayed loss of RGCs.

\section{Neutralization or genetic deletion of TNF- $\alpha$ prevents $\mathrm{OH}$-induced cell loss}

Although the preceding studies show that TNF- $\alpha$ can mimic certain features of glaucoma, they do not prove that it plays an essential role. To investigate this issue, we examined whether the effects of $\mathrm{OH}$ could be attenuated with either a neutralizing antiTNF- $\alpha$ antibody or by deletion of the TNF- $\alpha$ gene. A Spongel soaked with either an anti-TNF- $\alpha$ neutralizing antibody $(0.1 \mathrm{mg} /$ $\mathrm{ml}$ ) or a control antibody was placed directly on the optic nerve after angle closure. This treatment had no effect on IOP elevation after angle closure (data not shown). As expected, mice treated with the control antibody showed a 50\% reduction in $\mathrm{APC}^{+}$ oligodendrocytes by day 14 . However, the group treated with the TNF- $\alpha$ neutralizing antibody showed no detectable loss (Fig. $4 H, I)$. Deletion of the TNF- $\alpha$ gene likewise had no effect on IOP elevation after angle closure but eliminated oligodendrocyte loss after $\mathrm{OH}$ (Fig. 4J).

We investigated whether TNF- $\alpha$ accounts for the loss of RGCs by quantifying the survival of these cells after angle closure in TNF- $\alpha^{-1-}$ and wild-type mice. Whereas the number of DiI-labeled RGCs decreased significantly 3 weeks after inducing $\mathrm{OH}$ in wild-type mice, TNF- $\alpha^{-/-}$ mice showed no RGC loss even after 4 weeks of OH (Fig. 1C). Thus TNF- $\alpha$ appears to play a critical role in linking $\mathrm{OH}$ to the loss of oligodendrocytes and RGCs in the mouse model used here.

\section{The cytotoxic effects of $\mathrm{OH}$ and TNF- $\alpha$} are mediated via the TNFR2 receptor TNF- $\alpha$ acts via two known receptors, TNFR1 and TNFR2. To investigate the contribution of each of these receptors to the pathophysiological events described above, we induced $\mathrm{OH}$ in TNFR $1^{-1-}$ and TNFR2 ${ }^{-1-}$ knock-out mice. Lack of either of these genes did not alter IOP elevation after angle closure (Fig. 5A) nor the number of DiI-labeled RGCs nor the number of axons in the nerves of untreated animals (supplemental Table 1, available at www. jneurosci.org as supplemental material). At 4 weeks after elevating IOP, however, whereas wild-type mice and TNFR $1^{-1-}$ mice lost $>20 \%$ of DiI-labeled RGCs and axons in the affected eye, TNFR2 $2^{-1-}$ mice showed no RGC degeneration (Fig. $5 B-D)$. Oligodendrocyte loss in the optic nerve showed a similar pattern (Fig. 5E). In wild-type and TNFR $1^{-1-}$ mice the number of oligodendrocytes in the affected optic nerve declined by 35 and $40 \%$, respectively, after 4 weeks (Fig. $5 E$ ). In contrast, TNFR $2^{-1-}$ mice showed no such loss (Fig. 5E). Thus OH-induced oligodendrocyte degeneration and RGC loss were mediated by TNF- $\alpha$ acting via TNFR2. We also examined the effect of injecting TNF- $\alpha$ into the vitreous of mice deficient for either of the TNF receptors. TNF- $\alpha$ significantly decreased the number of $\mathrm{APC}^{+}$ oligodendrocytes in the optic nerves of TNFR $1^{-1-}$ mice, whereas TNFR2 ${ }^{-1-}$ mice showed no oligodendrocyte loss (Fig. 6).

\section{TNF- $\alpha$ leads to the activation of $\mathrm{CD} 11 \mathrm{~b}^{+}$microglia}

As noted above, intravitreal TNF- $\alpha$ injections resulted in a disorganized appearance of optic nerve oligodendrocytes within $1 \mathrm{~d}$. To investigate whether microglia contribute to this pathology, we performed immunohistochemistry in the optic nerve, using an antibody to CD11b, a marker for microglia. The number of $\mathrm{CD} 11 \mathrm{~b}^{+}$microglia was found to increase threefold above baseline 24-96 h after TNF- $\alpha$ injection; these cells appeared to be activated by virtue of being hypertrophied and amoeboid-shaped 
(Fig. $7 A, B$ ). The fact that $\mathrm{CD} 11 \mathrm{~b}^{+}$microglia become activated early suggests that they could play a role in the death of optic nerve oligodendrocytes.

\section{Mac-1-deficient (CD11b/CD18) mice are resistant to the effects of $\mathrm{OH}$ and TNF- $\alpha$}

To investigate whether activated microglia contribute to $\mathrm{OH}$-induced oligodendrocyte degeneration, we used $\mathrm{Mac}-1^{-1-}$ mice in which the gene for CD11b/CD18 is deleted. Mac- 1 is the integrin $\beta 2$, which has been shown to play a role in the recruitment and/or activation of leukocytes in various pathological conditions. Intravitreal TNF- $\alpha$ injections or direct application of a TNF- $\alpha$-soaked Spongel around the optic nerve was performed as described above, and surviving $\mathrm{APC}^{+}$oligodendrocytes were counted $14 \mathrm{~d}$ later. Absence of the Mac-1 gene did not prevent IOP elevation after angle closure (data not shown). However, unlike wild-type mice that lost $\sim 50 \%$ of oligodendrocytes after $14 \mathrm{~d}$ (Fig. 4G), Mac-1 ${ }^{-1-}$ mice showed no detectable oligodendrocyte loss after inducing $\mathrm{OH}$ by angle closure or after injecting TNF- $\alpha$ into the eye (Fig. $7 C-G$ ). As expected, Mac-1 $1^{-1-}$ mice showed no increase in the number of $\mathrm{CD}_{11 b^{+}}$microglia after the various treatments (data not shown). Finally, in contrast to the delayed loss of RGCs after $\mathrm{OH}$ was induced in wild-type mice, Mac-1 ${ }^{-/-}$mice showed no RGC loss after 4 weeks (Fig. 7H) (difference significant at $p<0.001$ ). Thus the cytotoxic effect of $\mathrm{OH}$ on oligodendrocytes and RGCs appears to involve a TNF- $\alpha$-induced activation of $\mathrm{CD} 11 \mathrm{~b}^{+}$microglia.

\section{Discussion}

The mechanisms by which elevated IOP leads to RGC loss in glaucoma have remained elusive. Genetic linkage analyses, postmortem studies, cell culture data, and in vivo studies have suggested that TNF- $\alpha$ may contribute to the pathophysiology of the disease; however, under certain conditions TNF- $\alpha$ is not cytotoxic to RGCs in a mixed cellular environment and is neuroprotective to RGCs after optic nerve injury in vivo (Tezel and Wax, 2000; Yan et al., 2000; Yuan and Neufeld, 2000, 2001; Funayama et al., 2004; Fuchs et al., 2005). Thus there is as yet no mechanistic understanding of how TNF- $\alpha$ might contribute to RGC loss in vivo nor any direct evidence that it actually mediates RGC cytotoxicity in glaucoma. Using a mouse model in which we elevate IOP via laser surgery, we show that TNF- $\alpha$ indeed does mediate the cytotoxic effects of $\mathrm{OH}$ on RGCs via an indirect route that involves microglial activation and the loss of oligodendrocytes. After laser surgery to produce angle closure in normal mice, IOP increased by $70 \%$ and remained elevated for at least 2 months. Elevated IOP was accompanied by an increase in TNF- $\alpha$ mRNA and protein within a few days, a loss of oligodendrocytes by 1-2 weeks, and a loss of RGCs beginning at 3-4 weeks (Fig. 8). Intravitreal administration of TNF- $\alpha$ to otherwise normal animals mimicked the degenerative effects of increased IOP, and, conversely, the effects of IOP were eliminated in mice with the
TNF- $\alpha$ gene deleted or by immune depletion of TNF- $\alpha$ in wildtype mice. The effect of TNF- $\alpha$ on oligodendrocyte loss was mediated primarily via the TNFR2 receptor, because the cytotoxic effects of either increased IOP or direct administration of TNF- $\alpha$ were eliminated in mice with the TNFR2 gene, although not the TNFR1 gene, deleted. The cytotoxic effect of $\mathrm{OH}$-induced TNF- $\alpha$ may be mediated by $\mathrm{CD} 11 \mathrm{~b}^{+}$microglia, although direct effects on other cell types cannot be ruled out. These cells increased rapidly in numbers and activation after TNF- $\alpha$ administration, and deletion of the gene for integrin $\beta 2$ (CD11b/CD18), which is important for microglial activation, prevented the loss of oligodendrocytes and RGCs after increasing IOP or after administering TNF- $\alpha$. Mouse models of $\mathrm{OH}$-induced glaucoma have been used previously to explore the role of caspases, calcineurin cleavage, and bcl-2 (B-cell CLL/lymphoma-2) family members in RGC death (Huang et al., 2005b; Ji et al., 2005) and the role of particular genetic mutations in bringing about $\mathrm{OH}$ (Gould et al., 2004; Mabuchi et al., 2004; Zillig et al., 2005). However, the present study represents the first to demonstrate a mechanistic link among increased intraocular pressure, TNF- $\alpha$ upregulation, and the loss of oligodendrocytes and RGCs in a mouse model of experimental glaucoma.

Oligodendrocytes are susceptible to oxidative stress (Haynes et al., 2005) and glutamate toxicity (Follett et al., 2004), which are thought to be related to the high basal metabolism of these cells in synthesizing lipids for myelin biosynthesis (Lane and Farlow, 2005). Oligodendrocyte degeneration plays an important role in demyelinating diseases such as multiple sclerosis, in which defined pathogens include microglia-derived TNF- $\alpha$, free radicals, 

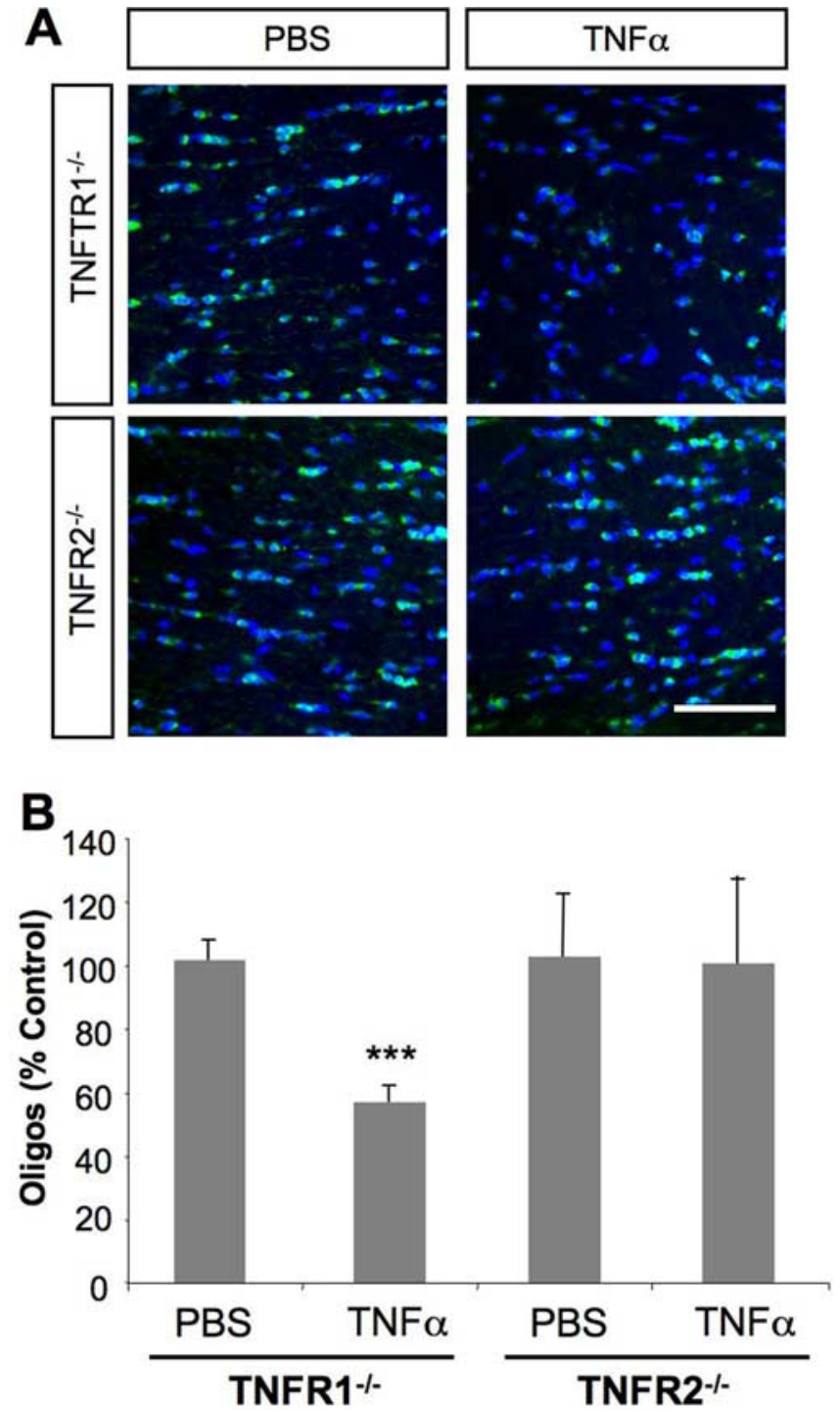

Figure 6. TNF- $\alpha$-induced oligodendrocyte loss depends on TNFR2. $A, A P C{ }^{+}$oligodendrocytes in optic nerves of TNFR1 ${ }^{-1-}$ or TNFR2 ${ }^{-1-}$ mice treated with PBS or TNF- $\alpha$. Scale bar, $100 \mu \mathrm{m} . B$, Quantitation of APC ${ }^{+}$oligodendrocyte survival after intravitreal injection of TNF- $\alpha$ in TNFR1 ${ }^{-1-}$ or TNFR2 ${ }^{-1-}$ mice. ${ }^{* * *} p<0.001$ as compared with PBS-injected controls in $\operatorname{TNFR}^{-1-}$ mice $(n=8)$.

and glutamate (Matute et al., 2001). In addition, TNF- $\alpha$ has been shown to potentiate AMPA/kainate-induced excitotoxicity in optic nerve oligodendrocytes (Miller et al., 2005) in vitro.

In our study increased IOP or intravitreal TNF- $\alpha$ injections led to a substantial loss of oligodendrocytes 1 week before any RGC loss could be detected. Previous studies have shown that intravitreal TNF- $\alpha$ injections lead to morphological changes in mouse oligodendrocytes (Butt and Jenkins, 1994) and that the loss of oligodendrocytes in the optic nerve affects the susceptibility of axons to excitotoxicity (Coleman, 2005; Stys, 2005). In addition, TNF- $\alpha$ has been shown to cause axonal loss and subsequent death of RGCs in rats (Kitaoka et al., 2006). Axonal damage resulting from nerve injury has been shown in many studies to induce a delayed loss of RGC somata (Nakazawa et al., 2002a). Together, these observations suggest the possibility that $\mathrm{OH}$ induced oligodendrocyte loss leads to a loss of RGC axons, followed by a loss of RGC somata.

A number of mechanisms have been proposed to underlie
RGC loss in glaucoma, including a loss of retrograde transport of essential neurotrophins (Pease et al., 2000), degradation of extracellular matrix (Yan et al., 2000; Yuan and Neufeld, 2001), excitotoxicity (Guo et al., 2006), and the activation of calcineurin and caspases (Huang et al., 2005b). The present results indicate that suppression of TNF- $\alpha$ is sufficient to prevent the loss of oligodendrocytes and RGCs in the mouse model of glaucoma used here. As far as we know, this is the first demonstration of oligodendrocyte loss in experimental glaucoma. Whether this applies to the human disease remains to be determined. This finding suggests that TNF- $\alpha$ may contribute directly or indirectly to at least some of the other pathological signs associated with glaucoma in patients and in animal models, such as caspase activation (Huang et al., 2005a), calcineurin cleavage (Huang et al., 2005b), activation of microglia (Yuan and Neufeld, 2001) and astrocytes (Yan et al., 2000), and MAPK (mitogen-activated protein kinase) phosphorylation (Tezel et al., 2003). However, we have not examined this issue explicitly. Once oligodendrocytes have been damaged, demyelinated axons are more susceptible than myelinated axons to cytotoxic factors (Coleman, 2005). Thus the protection of oligodendrocytes in glaucoma may represent a useful strategy for preventing the loss of RGCs.

Activated microglia are seen in the optic nerve head of glaucoma patients (Yuan and Neufeld, 2001), and microarray analyses with experimental glaucoma tissues (Ahmed et al., 2004) also have implicated the immune system in $\mathrm{OH}$-induced neuronal degeneration (Tezel and Wax, 2004). Microglia, an important component of the innate immune system of the eye (Chen et al., 2002), express CD11b in the retina and optic nerve (Chen et al., 2002). In the present study Mac-1-deficient (CD11b/CD18) mice proved to be resistant to TNF- $\alpha$ - and $\mathrm{OH}$-induced neuronal degeneration. Thus $\mathrm{CD} 11 \mathrm{~b}^{+}$microglia appear to play a central role in TNF- $\alpha$ - or $\mathrm{OH}$-induced neuronal degeneration, and the suppression of microglia with drugs such as minocycline may represent yet another treatment for glaucoma (Tikka and Koistinaho, 2001; Levkovitch-Verbin et al., 2006).

Our data show that $\mathrm{OH}$-induced neuronal degeneration depends on the TNFR2 receptor, but not TNFR1. At first glance this finding might appear to be inconsistent with the fact that TNFR1 has an intracellular death domain and that its activation elicits caspase pathways that lead to neuronal cell death. TNFR2, on the other hand, activates the Akt signaling pathway and promotes cell survival (Fontaine et al., 2002), at least in neurons. Microglia express both TNFR1 and TNFR2, whereas oligodendrocytes and astrocytes primarily express TNFR1 (Dopp et al., 1997; Bohatschek et al., 2004), and recruited macrophages express TNFR2 (Dziewulska and Mossakowski, 2003). Signaling via TNFR2 is important for cytotoxic lymphocyte recruitment in the axotomized facial motor nucleus (Raivich et al., 2003) and suppresses oxidative stress in microglia (Dopp et al., 2002). Thus it appears as if the effects of TNF- $\alpha$ on microglia, mediated via TNFR2, lead to the loss of other cells, presumably because of the release of cytotoxic agents, including reactive oxygen species, nitric oxide, and TNF- $\alpha$.

In conclusion, our studies in an experimental mouse model show that TNF- $\alpha$ plays a central role in the pathophysiological events that result from elevated IOP. TNF- $\alpha$ is upregulated as a consequence of increasing IOP, and, like IOP, exogenous TNF- $\alpha$ leads to a loss of oligodendrocytes and a delayed loss of RGCs (Fig. 8). Our study is the first to show that a functional blockade of TNF- $\alpha$ with an anti-TNF- $\alpha$ blocking antibody or deletion of the gene encoding TNF- $\alpha$ in genetically altered mice completely prevents $\mathrm{OH}$-induced oligodendrocyte degeneration and the sec- 
ondary loss of RGCs. The toxic effects of TNF- $\alpha$ are mediated via TNFR2 receptors on $\mathrm{CD} 11 \mathrm{~b}^{+}$microglia, which are likely to be the final killers of oligodendrocytes and, indirectly, of RGCs. Interference with TNF- $\alpha$ by using a blocking antibody has been applied in the treatment of other inflammatory diseases (De Keyser et al., 2006); other possible approaches include the use of a soluble receptor (Alldred, $2001)$ or a TACE (TNF- $\alpha$-converting enzyme) inhibitor (Moss et al., 2001). Blockade of TNF- $\alpha$ function and downstream microglial activation may be an important approach for the treatment of glaucoma.

\section{References}

Ahmed F, Brown KM, Stephan DA, Morrison JC, Johnson EC, Tomarev SI (2004) Microarray analysis of changes in mRNA levels in the rat retina after experimental elevation of intraocular pressure. Invest Ophthalmol Vis Sci 45:1247-1258.

Aihara M, Lindsey JD, Weinreb RN (2003) Experimental mouse ocular hypertension: establishment of the model. Invest Ophthalmol Vis Sci 44:4314-4320.

Alldred A (2001) Etanercept in rheumatoid arthritis. Expert Opin Pharmacother 2:1137-1148.

Bohatschek M, Kloss CU, Hristova M, Pfeffer K, Raivich G (2004) Microglial major histocompatibility complex glycoprotein-1 in the axotomized facial motor nucleus: regulation and role of tumor necrosis factor receptors 1 and 2. J Comp Neurol 470:382-399.

Brouckaert P, Libert C, Everaerdt B, Takahashi N, Cauwels A, Fiers W (1993) Tumor necrosis factor, its receptors and the connection with interleukin 1 and interleukin 6. Immunobiology 187:317-329.

Butt AM, Jenkins HG (1994) Morphological changes in oligodendrocytes in the intact mouse optic nerve following intravitreal injection of tumour necrosis factor. J Neuroimmunol 51:27-33.

Chen L, Yang P, Kijlstra A (2002) Distribution, markers, and functions of retinal microglia. Ocul Immunol Inflamm 10:27-39.

Coleman M (2005) Axon degeneration mechanisms: commonality amid diversity. Nat Rev Neurosci 6:889-898.

Cordeiro MF, Guo L, Luong V, Harding G, Wang W, Jones HE, Moss SE, Sillito AM, Fitzke FW (2004) Real-time imaging of single nerve cell apoptosis in retinal neurodegeneration. Proc Natl Acad Sci USA 101:13352-13356

De Keyser F, Van den Bosch F, Mielants H (2006) Anti-TNF- $\alpha$ therapy in ankylosing spondylitis. Cytokine 33:294-298.

Diem R, Meyer R, Weishaupt JH, Bahr M (2001) Reduction of potassium currents and phosphatidylinositol 3-kinase-dependent AKT phosphorylation by tumor necrosis factor- $\alpha$ rescues axotomized retinal ganglion cells from retrograde cell death in vivo. J Neurosci 21:2058-2066.

Dopp JM, Mackenzie-Graham A, Otero GC, Merrill JE (1997) Differential expression, cytokine modulation, and specific functions of type- 1 and type-2 tumor necrosis factor receptors in rat glia. J Neuroimmunol 75:104-112.

Dopp JM, Sarafian TA, Spinella FM, Kahn MA, Shau H, de Vellis J (2002) Expression of the p75 TNF receptor is linked to TNF-induced NF $\kappa$ B translocation and oxyradical neutralization in glial cells. Neurochem Res 27:1535-1542.

Dziewulska D, Mossakowski MJ (2003) Cellular expression of tumor necro-

\begin{tabular}{|c|c|c|c|c|c|c|c|c|c|}
\hline Symptom (weeks) & 0 & 1 & 2 & 3 & 4 & 5 & 6 & 7 & 8 \\
\hline $\begin{array}{l}\text { TNF } \alpha \text { up-regulation } \\
\text { Microglial activation } \\
\text { Oligodendrocyte loss } \\
\text { RGC loss }\end{array}$ & & & & & & & & & \\
\hline
\end{tabular}

Figure 8. Schematic timeline of events. TNF- $\alpha$ is upregulated rapidly after increasing intraocular pressure. This upregulation is followed by a rapid increase in microglial activation in the nerve, and by week 2 oligodendrocyte loss can be seen. Significant RGC death appears by week 4.

sis factor- $\alpha$ and its receptors in human ischemic stroke. Clin Neuropathol 22:35-40.

Follett PL, Deng W, Dai W, Talos DM, Massillon LJ, Rosenberg PA, Volpe JJ, Jensen FE (2004) Glutamate receptor-mediated oligodendrocyte toxicity in periventricular leukomalacia: a protective role for topiramate. J Neurosci 24:4412-4420.

Fontaine V, Mohand-Said S, Hanoteau N, Fuchs C, Pfizenmaier K, Eisel U (2002) Neurodegenerative and neuroprotective effects of tumor necrosis 
factor (TNF) in retinal ischemia: opposite roles of TNF receptor 1 and TNF receptor 2. J Neurosci 22:RC216(1-7).

Fuchs C, Forster V, Balse E, Sahel JA, Picaud S, Tessier LH (2005) Retinalcell-conditioned medium prevents TNF- $\alpha$-induced apoptosis of purified ganglion cells. Invest Ophthalmol Vis Sci 46:2983-2991.

Funayama T, Ishikawa K, Ohtake Y, Tanino T, Kurosaka D, Kimura I, Suzuki K, Ideta H, Nakamoto K, Yasuda N, Fujimaki T, Murakami A, Asaoka R, Hotta Y, Tanihara H, Kanamoto T, Mishima H, Fukuchi T, Abe H, Iwata $\mathrm{T}$, et al. (2004) Variants in optineurin gene and their association with tumor necrosis factor- $\alpha$ polymorphisms in Japanese patients with glaucoma. Invest Ophthalmol Vis Sci 45:4359-4367.

Gould DB, Smith RS, John SW (2004) Anterior segment development relevant to glaucoma. Int J Dev Biol 48:1015-1029.

Guo L, Salt TE, Maass A, Luong V, Moss SE, Fitzke FW, Cordeiro MF (2006) Assessment of neuroprotective effects of glutamate modulation on glaucoma-related retinal ganglion cell apoptosis in vivo. Invest Ophthalmol Vis Sci 47:626-633.

Haynes RL, Baud O, Li J, Kinney HC, Volpe JJ, Folkerth DR (2005) Oxidative and nitrative injury in periventricular leukomalacia: a review. Brain Pathol 15:225-233.

Heijl A, Leske MC, Bengtsson B, Hyman L, Bengtsson B, Hussein M (2002) Reduction of intraocular pressure and glaucoma progression: results from the early manifest glaucoma trial. Arch Ophthalmol 120:1268-1279.

Huang W, Dobberfuhl A, Filippopoulos T, Ingelsson M, Fileta JB, Poulin NR, Grosskreutz CL (2005a) Transcriptional up-regulation and activation of initiating caspases in experimental glaucoma. Am J Pathol 167:673-681.

Huang W, Fileta JB, Dobberfuhl A, Filippopolous T, Guo Y, Kwon G, Grosskreutz CL (2005b) Calcineurin cleavage is triggered by elevated intraocular pressure, and calcineurin inhibition blocks retinal ganglion cell death in experimental glaucoma. Proc Natl Acad Sci USA 102:12242-12247.

Iwase A, Suzuki Y, Araie M, Yamamoto T, Abe H, Shirato S, Kuwayama Y, Mishima HK, Shimizu H, Tomita G, Inoue Y, Kitazawa Y (2004) The prevalence of primary open-angle glaucoma in Japanese: the Tajimi study. Ophthalmology 111:1641-1648.

Ji J, Chang P, Pennesi ME, Yang Z, Zhang J, Li D, Wu SM, Gross RL (2005) Effects of elevated intraocular pressure on mouse retinal ganglion cells. Vision Res 45:169-179.

John SW (2005) Mechanistic insights into glaucoma provided by experimental genetics: the Cogan lecture. Invest Ophthalmol Vis Sci 46:2649-2661.

Kitaoka Y, Kitaoka Y, Kwong JM, Ross-Cisneros FN, Wang J, Tsai RK, Sadun AA, Lam TT (2006) TNF- $\alpha$-induced optic nerve degeneration and nuclear factor- $\kappa$ B p65. Invest Ophthalmol Vis Sci 47:1448-1457.

Lane RM, Farlow MR (2005) Lipid homeostasis and apolipoprotein E in the development and progression of Alzheimer's disease. J Lipid Res 46:949-968.

Levin LA (2003) Retinal ganglion cells and neuroprotection for glaucoma. Surv Ophthalmol 48:S21-S24.

Levkovitch-Verbin H, Kalev-Landoy M, Habot-Wilner Z, Melamed S (2006) Minocycline delays death of retinal ganglion cells in experimental glaucoma and after optic nerve transection. Arch Ophthalmol 124:520-526.

Lindsey JD, Weinreb RN (2005) Elevated intraocular pressure and transgenic applications in the mouse. J Glaucoma 14:318-320.

Mabuchi F, Lindsey JD, Aihara M, Mackey MR, Weinreb RN (2004) Optic nerve damage in mice with a targeted type I collagen mutation. Invest Ophthalmol Vis Sci 45:1841-1845.

Matsubara A, Nakazawa T, Husain D, Iliaki E, Connolly E, Michaud NA, Gragoudas ES, Miller JW (2006) Investigating the effect of ciliary body photodynamic therapy in a glaucoma mouse model. Invest Ophthalmol Vis Sci 47:2498-2507.

Matute C, Alberdi E, Domercq M, Perez-Cerda F, Perez-Samartin A, Sanchez-Gomez MV (2001) The link between excitotoxic oligodendroglial death and demyelinating diseases. Trends Neurosci 24:224-230.
Miller BA, Sun F, Christensen RN, Ferguson AR, Bresnahan JC, Beattie MS (2005) A sublethal dose of TNF $\alpha$ potentiates kainate-induced excitotoxicity in optic nerve oligodendrocytes. Neurochem Res 30:867-875.

Moss ML, Jin SL, Becherer JD, Bickett DM, Burkhart W, Chen WJ, Hassler D, Leesnitzer MT, McGeehan G, Milla M, Moyer M, Rocque W, Seaton T, Schoenen F, Warner J, Willard D (1997) Structural features and biochemical properties of TNF- $\alpha$ converting enzyme (TACE). J Neuroimmunol 72:127-129.

Moss ML, White JM, Lambert MH, Andrews RC (2001) TACE and other ADAM proteases as targets for drug discovery. Drug Discov Today 6:417-426.

Nakazawa T, Tomita H, Yamaguchi K, Sato Y, Shimura M, Kuwahara S, Tamai M (2002a) Neuroprotective effect of nipradilol on axotomized rat retinal ganglion cells. Curr Eye Res 24:114-122.

Nakazawa T, Tamai M, Mori N (2002b) Brain-derived neurotrophic factor prevents axotomized retinal ganglion cell death through MAPK and PI3K signaling pathways. Invest Ophthalmol Vis Sci 43:3319-3326.

Nakazawa T, Morii H, Tamai M, Mori N (2005) Selective up-regulation of RB3/stathmin4 by ciliary neurotrophic factor following optic nerve axotomy. Brain Res 861:399-407.

Pease ME, McKinnon SJ, Quigley HA, Kerrigan-Baumrind LA, Zack DJ (2000) Obstructed axonal transport of BDNF and its receptor TrkB in experimental glaucoma. Invest Ophthalmol Vis Sci 41:764-774.

Quigley HA (1996) Number of people with glaucoma worldwide. Br J Ophthalmol 80:389-393.

Raivich G, Bohatschek M, Werner A, Jones LL, Galiano M, Kloss CU, Zhu XZ, Pfeffer K, Liu ZQ (2003) Lymphocyte infiltration in the injured brain: role of proinflammatory cytokines. J Neurosci Res 72:726-733.

Resnikoff S, Pascolini D, Etya'ale D, Kocur I, Pararajasegaram R, Pokharel GP, Mariotti SP (2004) Global data on visual impairment in the year 2002. Bull World Health Organ 82:844-851.

Shohami E, Ginis I, Hallenbeck JM (1999) Dual role of tumor necrosis factor alpha in brain injury. Cytokine Growth Factor Rev 10:119-130.

Stys PK (2005) General mechanisms of axonal damage and its prevention. J Neurol Sci 233:3-13.

Tartaglia LA, Goeddel DV (1992) Two TNF receptors. Immunol Today 13:151-153.

Tezel G, Wax MB (2000) Increased production of tumor necrosis factor- $\alpha$ by glial cells exposed to simulated ischemia or elevated hydrostatic pressure induces apoptosis in cocultured retinal ganglion cells. J Neurosci 20:8693-8700.

Tezel G, Wax MB (2004) The immune system and glaucoma. Curr Opin Ophthalmol 15:80-84.

Tezel G, Chauhan BC, LeBlanc RP, Wax MB (2003) Immunohistochemical assessment of the glial mitogen-activated protein kinase activation in glaucoma. Invest Ophthalmol Vis Sci 44:3025-3033.

Tikka TM, Koistinaho JE (2001) Minocycline provides neuroprotection against $N$-methyl-D-aspartate neurotoxicity by inhibiting microglia. J Immunol 166:7527-7533.

Weinreb RN, Khaw PT (2004) Primary open-angle glaucoma. Lancet 363:1711-1720.

Yan X, Tezel G, Wax MB, Edward DP (2000) Matrix metalloproteinases and tumor necrosis factor alpha in glaucomatous optic nerve head. Arch Ophthalmol 118:666-673.

Yin Y, Henzl MT, Lorber B, Nakazawa T, Thomas TT, Jiang F, Langer R, Benowitz LI (2006) Oncomodulin is a macrophage-derived signal for axon regeneration in retinal ganglion cells. Nat Neurosci 9:843-852.

Yuan L, Neufeld AH (2000) Tumor necrosis factor- $\alpha$ : a potentially neurodestructive cytokine produced by glia in the human glaucomatous optic nerve head. Glia 32:42-50.

Yuan L, Neufeld AH (2001) Activated microglia in the human glaucomatous optic nerve head. J Neurosci Res 64:523-532.

Zillig M, Wurm A, Grehn FJ, Russell P, Tamm ER (2005) Overexpression and properties of wild-type and Tyr437His mutated myocilin in the eyes of transgenic mice. Invest Ophthalmol Vis Sci 46:223-234. 